\title{
Limnological parameters and metals concentrations in water in three lagoons of the metropolitan region of Salvador, Bahia, Brazil
}

\author{
Ana C. M. SILVA',2, Isabel H. d. S. AZEVEDO'1, Manuel V. P. GONÇALVES ${ }^{1,2}$, Alexandre D. D. \\ MILAZZO' ${ }^{1}$, Sérgio A. d. M. NASCIMENTO'1,2 \& Manoel J. M. CRUZ ${ }^{1,2}$
}

\begin{abstract}
1 Programa de Pós-graduação em Geologia, Universidade Federal da Bahia. Rua Barão de Jeremoabo, s/n, CEP 40.170-115, Salvador, Bahia, Brasil (anacarinams@gmail.com; ih.azevedo@uol.com.br; hidrovitor81@gmail.com; alexandremilazzo@gmail.com; jc9508@gmail.com; sergiomn@ufba.br).
\end{abstract}

2 Grupo de Estudos Geoquímica das Interfaces.

\begin{abstract}
This work aims to describe the seasonal variability of physicochemical and metal parameters in three lakes of the city of Salvador-BA (Pituaçú and Paixão lagoons and Tororó dike), between 2014 and 2017, with special emphasis on regarding classification and suitability for the use for amateur fishing, recreation, conservation, and landscape harmony. Physicochemical parameters were measured in situ and aliquots of water were collected for laboratory analysis at different seasonal periods from 2014 to 2017. Metal concentrations in water (Al, As, Ba, B, $\mathrm{Cd}, \mathrm{Ca}, \mathrm{Cr}, \mathrm{Co}, \mathrm{Cu}, \mathrm{Fe}, \mathrm{Pb}, \mathrm{Mg}, \mathrm{Mn}, \mathrm{Hg}, \mathrm{Ni}, \mathrm{K}, \mathrm{Se}, \mathrm{V}$, and $\mathrm{Zn}$ ) were determined by ICP-OES. The $\mathrm{pH}$ ranged from 5.5-8.9 (7.5 \pm 0.7$)$; water temperature, 22.0-33.20 (26.68 \pm 2.11$)^{\circ} \mathrm{C}$; dissolved oxygen, 0.72-10.87 (6.31 \pm 1.65$) \mathrm{mg} . \mathrm{L}-1$; turbidity, 0.43-188.0 (23.54 \pm 31.86$)$ NTU and conductivity, 0.192.60 (0.44 \pm 0.35$)$ mS.cm-1. Fe (all lagoons), Pb and Mn (Paixão and Pituaçú lagoons) and Al (Pituaçu lagoon) presented average values above the maximum limits stipulated by CONAMA evidencing the degradation of water quality. Water parameters were considered appropriate for its current use, although commonly the dissolved oxygen and turbidity values are not consistent with the standard stipulated in CONAMA Resolution 357/05 (> 5 mg.L-1 for dissolved oxygen and up to 100 NTU for turbidity). Attention should be drawn especially to the values obtained for dissolved metals (especially Fe, $\mathrm{Pb}, \mathrm{Mn}$, and $\mathrm{Al}$ ), which have been shown to be at certain seasonal periods or at constant ( $\mathrm{Mn}$ ) levels dangerously above the stipulated limits. Due to the possibility of harmful effects, there is a need for intervention and protection in these areas, and continuous monitoring, aiming to improve water quality and respond to major uses.
\end{abstract}

Keywords. water quality, lentic environments, monitoring, hydrochemistry.

Resumo. PARÂMETROS LIMNOLÓGICOS E CONCENTRAÇÃO DE METAIS NA ÁGUA EM TRÊS LAGOAS DA REGIÃO METROPOLITANA DE SALVADOR, BAHIA, BRASIL. Este trabalho objetiva descrever a variabilidade sazonal dos parâmetros físico-químicos e de metais em lagoas da cidade de Salvador, Bahia (lagoas de Pituaçú, Paixão e Tororó), entre os anos de 2014 e 2017, com especial ênfase nas orientações quanto à classificação e adequação aos usos para a pesca amadora, recreação, conservação e harmonia paisagística. Foram mensurados in situ os parâmetros físico-químicos e tomadas alíquotas de água para as análises laboratoriais, em períodos sazonais distintos entre os anos de 2014 e 2017. As concentrações dos metais em água (Al, As, Ba, B, Cd, $\mathrm{Ca}, \mathrm{Cr}, \mathrm{Co}, \mathrm{Cu}, \mathrm{Fe}, \mathrm{Pb}, \mathrm{Mg}, \mathrm{Mn}, \mathrm{Hg}, \mathrm{Ni}, \mathrm{K}$, Se, $\mathrm{V}$ e Zn) foram determinadas por ICP-OES. O pH variou entre 5,5-8,9 (7,5 $\pm 0,7)$; temperatura da água, 22,0-33,20 (26,68 $\pm 2,11){ }^{\circ} \mathrm{C}$; oxigênio dissolvido, 0,72-10,87 (6,31 $\pm 1,65) \mathrm{mg} . \mathrm{L}-1 ;$ turbidez, 0,43-188,0 $(23,54 \pm 31,86)$ NTU e condutividade, 0,19-2,60 $(0,44 \pm 0,35)$ mS.cm-1. O Fe (todas as lagoas), Pb e Mn (Lagoa da Paixão e Pituaçú) e Al (Lagoa de Pituaçu) apresentaram valores médios acima dos limites máximos estipulados pelo CONAMA evidenciando a degradação da qualidade da água. Os parâmetros da água foram considerados adequados para sua atual utilização, embora comumente os valores de oxigênio dissolvido e turbidez não estejam condizentes com o padrão estipulado na Resolução CONAMA 357/05 (> $5 \mathrm{mg} \cdot \mathrm{aL}^{-1}$ para oxigênio dissolvido e até 100 NTU para turbidez). Ressalta-se a necessidade de atenção principalmente aos valores obtidos para os metais dissolvidos (em especial $\mathrm{Fe}, \mathrm{Pb}, \mathrm{Mn}$ e Al), que se mostraram, em determinados períodos sazonais ou de forma constante ( $\mathrm{Mn}$ ) em 
níveis perigosamente acima dos limites estipulados. Devido à possibilidade de efeitos nocivos, destaca-se a necessidade de intervenção e proteção nestas áreas, e contínuo monitoramento, visando melhorar a qualidade da água e responder aos usos preponderantes.

Palavras-chave. qualidade da água, ambientes lênticos, monitoramento, hidroquímica.

\section{Introduction}

Lakes and reservoirs are considered important vehicles for biodiversity conservation, as they have well-defined ecotones (HillbrichtIlkowska \& Pieczynska, 2012), which is associated with their long residence time in the environment.

The quality of a body of water is defined in terms of chemical, physical and biological conditions which are associated with a series of processes that occur in the water body and its drainage basin. It means, therefore, that even if there is no interference from the anthropic origin, water quality can change according to geological, geographical, and seasonal conditions (Chitmanat \& Siripen, 2010)

Some natural physicochemical parameters are commonly used for the study of water quality in lakes and reservoirs. These, besides influencing the dynamics of the environment, are limiting factors for the survival of aquatic organisms (fauna and flora). The parameters that exert the greatest influence for determining water quality are $\mathrm{pH}$, temperature, dissolved oxygen, turbidity, and conductivity (Alves et al., 2010). Other quality determining characteristics also refer to biological conditions such as organic contaminants, metal contamination, pesticides, and pathogenic microorganisms.

The presence of metals is a natural characteristic of different environments and varies according to the geological characteristics of each region. In aquatic ecosystems, the most common occurrence is of geological origin through weathering and soil leaching. However, other anthropic interferences can contribute, for example, waste disposal, nearby vehicle transport, rail traffic, industrial and agricultural activities, and atmospheric deposition (Bucci et al., 2015).

Precipitation has a strong influence on the dynamics of the physical and chemical characteristics of water on lakes, as it boosts the supply of nutrients and particulate matter from adjacent areas. These seasonal changes increase the availability of these nutrients to primary producing organisms or conditioning their characteristics according to the water/ particulate matter interaction. Studies demonstrate increased concentrations in metal elements in surface waters of lakes such as $\mathrm{Pb}$, Zn (Lindström, 2001; Bonacin, 2001), Cu, Cr, Ni (Lindström, 2001) in small lakes from tropical areas during times of heavy rainfall.

The availability of metals in the environment, in particular micronutrients, such as $\mathrm{Cu}$ and $\mathrm{Zn}$, is essential for the existence of certain metabolic activities, but may have a negative impact on the aquatic ecosystem, and/or turn the water inappropriate for the potential intended use. The toxicity of heavy metals depends on the type of metal, the compound formed in association with other elements, the amount deposited on the organism, and the length of action of the metal (Lawson, 2011). Other environmental characteristics such as physicochemical conditions, presence of organic matter, and particulate matter in the environment, are also determinants for its harmfulness.

Lakes and lagoons are among the most biomass-productive ecosystem on the planet, which requires intensive care to determine the existence of metals and behavior of physicochemical parameters in these environments for better pollution control and management (Lawson, 2011). Monitoring of metal concentrations in water from lentic ecosystems is recommended in urban areas and/or with a history of recorded anthropic pollution, such as Pituaçu and Paixão lagoons and Tororó Dike.

Despite the periodic monitoring of the responsible agencies, scientific dissemination regarding the presence of metals and their seasonal variation in the lagoons in Salvador is scarce. However, some studies highlight the existence of these elements in sediments and 
dissolved in water.

Silva et al. (2017) identified the presence of $\mathrm{Al}, \mathrm{Cu}, \mathrm{Fe}, \mathrm{Mn}$, and $\mathrm{V}$ in the Pituaçú lagoon sediment, alerting to the need to expand environmental preservation actions, thus avoiding the accumulation of these metals at toxic levels to water. The same trend occurs in nearby lagoons, as illustrated by Souza (2017), in which significant seasonal differences in the physical, chemical, and iron concentration parameters in three coastal lagoons (Camarão, Vitória, and Junco) were confirmed, located north of the city of Salvador. Other studies also show the presence of contamination of metals in different aquatic environments, such as groundwater (Carmo, 2015) and estuarine environments (Andrade, 2011; Escobar, 2011) in Salvador, and in lagoons of other municipalities of Bahia (Santos, 2012).

This study aimed to describe the seasonal variability (dry/rainy) by quantifying and comparing metal data and physicochemical parameters from 2014 to 2017 in Pituaçú, Paixão lagoons and Tororó dike (Salvador, Bahia), assessing their suitability for use and classification suggested by the responsible public agencies.

\section{Methods}

The lentic ecosystems Tororó dike, Paixão lagoon and Pituaçu lagoon belong to the municipality of Salvador, Bahia, Brazil. The municipality of Salvador is located between the geographical coordinates $12^{\circ} 53^{\prime} 54^{\prime \prime}$ and $13^{\circ} 00^{\prime} 59^{\prime \prime}$ south latitude and $38^{\circ} 18^{\prime} 31^{\prime \prime}$ and 38 $32^{\prime} 20^{\prime \prime}$ west longitude. Its administrative jurisdiction includes a continental part and an island part with three islands located in Todos os Santos Bay (Nascimento, 2008).

The Recôncavo Region of Bahia, where is located the city of Salvador (Fig. 1), presents a super humid or equatorial tropical humid climate classification. The total rainfall of the month with the highest drought is greater than $60 \mathrm{~mm}$, with the most rainfall from March to August, exceeding the total of 1,500 mm annually. In the warmer months (January and February) the temperature is between 24 and $27^{\circ} \mathrm{C}$. The average annual rainfall is $1,781 \mathrm{~mm}$ and the average annual temperature is $25.2^{\circ} \mathrm{C}$ (Ramos et al., 2009).
In a geological context, Salvador is characterized by Precambrian rocks of the crystalline basement partially covered by the Cretaceous sediments of the Barreiras Formation (Santos \& Lima, 2005). This formation consists of a continental sediment package, little lithified and with different colors. A great diversity of high to medium-grade metamorphic lithotypes is highlighted, consisting of metamorphized, granitic, and basaltic rocks (Souza et al., 2010) in addition to amphibolite facies rocks (Barbosa et al., 2005) and sedimentary clay cover, sands, and gravels, with irregular stratification and usually indistinct (Tourinho, 2008).

The formation of lagoons is conditioned to the existence of valleys and erudite zones, which intercept the piezometric level. Other lagoons, closer to the coastal strip, were formed in the Quaternary, due to sea-level rise, mainly during the last transgressive period, being filled, in part, by marine deposits rich in shells, allowing to date the final phase of the antepenultimate marine quaternary transgression between 6500 and 5000 BP (Nascimento \& Barbosa, 2010).

In the fieldwork, 12 points were selected distributed in water sampling stations in three lentic ecosystems (Pituaçú lagoon, Paixão lagoon, and Tororó dike). Four sampling campaigns were conducted in July and November of 2016 and 2017. Data from previous years (2014 and 2015) included information from the EMBASA (Bahia Water and Sanitation Company) database and the Monitora program (executed by the Coordination of Monitoring of Environmental and Water Resources of the Institute of Environment and Water Resources - INEMA).

The sampling periods respected the seasonal determination proposed by Santos et al. (2016) who defined, based on the rainfall variability of the city of Salvador, the months of April, May, June, and July as the wettest four-month period, and the months of August, September, October, and November as the driest four-month period, based on monthly precipitation totals obtained by the National Institute of Meteorology over 51 years (1961-2011). The sampling was performed in the morning and on days without rain, following the procedures recommended by Brazilian National Standards Organization (ABNT, 1987). 


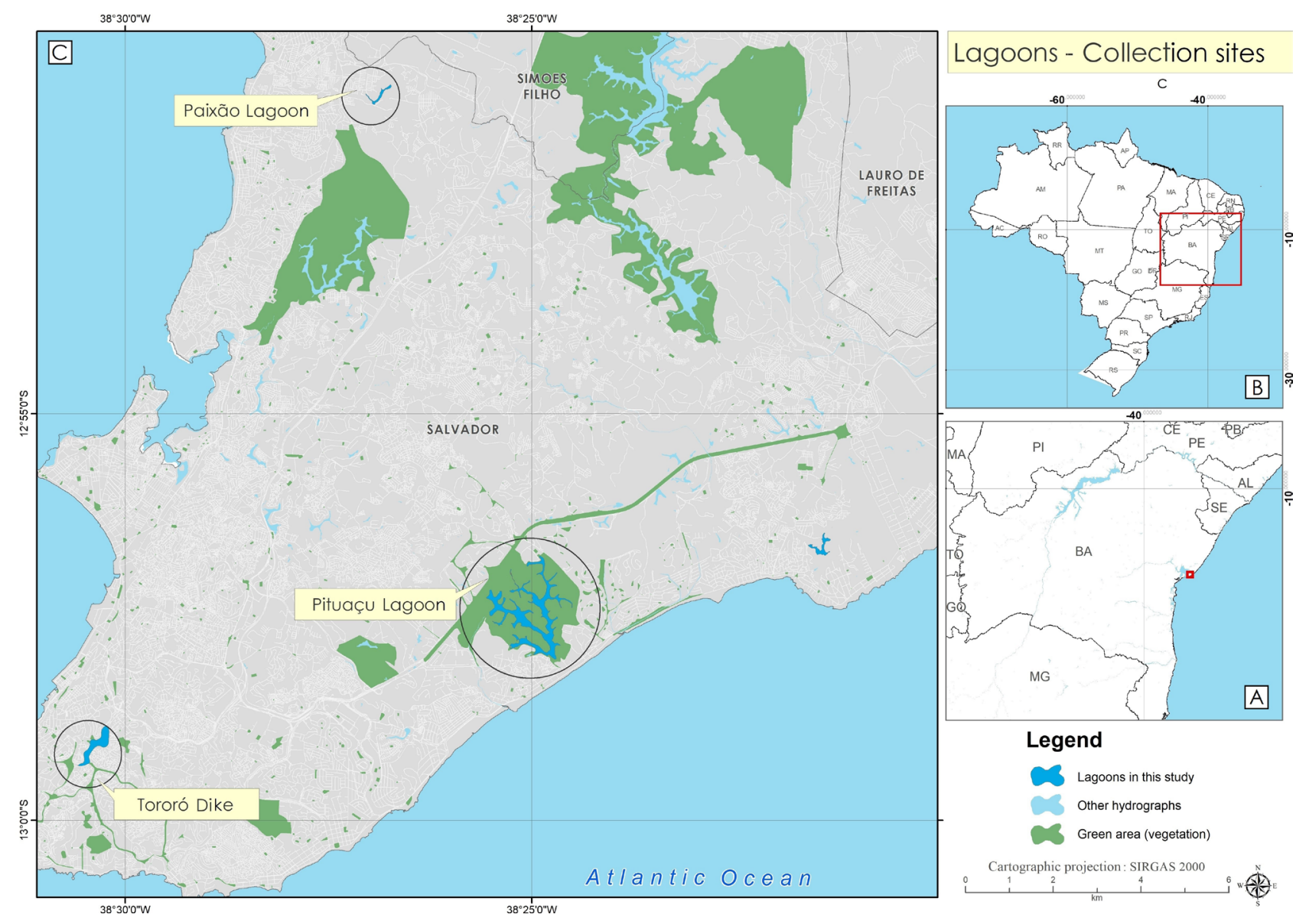

Figure 1. Location map of the city of Salvador (A), state of Bahia (B), highlighting the sampling sites (Pituaçu Lagoon, Paixão Lagoon, and Tororó Dike) (C).

Figura 1. Mapa de localização da cidade de Salvador (A), Estado da Bahia (B), destacando os locais de coleta (Lagoas de Pituaçú, Paixão e Dique do Tororó) (C).

The rainfall and air temperature data used in this work come from the surface weather station database of the National Institute of Meteorology (INMET), in the city of Salvador. Monthly precipitation averages $(\mathrm{mm})$ and temperature $\left({ }^{\circ} \mathrm{C}\right.$ ) were obtained, between 2014 and 2018 (Fig. 2).

Simple random sampling points were previously defined, ensuring that the data obtained had equal possibilities, that is, that would not be affected by the choice of the sampler technician. The number and location of points were determined in accordance with the extent of the body of water and based on adequacy with previously verified data (Tab. 1). Sampling was performed following the recommendations of the water collection standards in Standard Methods for the Examination of Water and Wastewater (WEF, 2005).

The maximum sample acquisition depth was directly fixed at $30-40 \mathrm{~cm}$ deep of the water body through inert, properly identified, and sterilized containers. The samples were then preserved in ice-cold Styrofoam boxes and kept at a temperature of approximately $4^{\circ} \mathrm{C}$ to preserve their properties. The analysis took place in the laboratories of Plasma and the Center for Environmental Studies (IGEO/UFBA) and the laboratory of the Department of Environmental Engineering (Polytechnic School/UFBA). This process was completed in less than $24 \mathrm{~h}$, according to the due date for analysis of each parameter in the samples.

The physicochemical parameters $(\mathrm{pH}$, conductivity, temperature, dissolved oxygen, turbidity, and total dissolved solids) were analyzed in situ and during collection using a pre-calibrated multiparameter probe (Horiba 104 U-54 Multiparameter Water Quality Checker). CONAMA Resolution No. 357/05 establishes 
a legal limit for both measured parameters and conducting field analysis with the aid of a portable probe enables greater data consistency, considering the local climate at the exact time of collection.

The concentrations of metals (Al, As, Ba, B, $\mathrm{Cd}, \mathrm{Ca}, \mathrm{Cr}, \mathrm{Co}, \mathrm{Cu}, \mathrm{Fe}, \mathrm{Pb}, \mathrm{Mg}, \mathrm{Mn}, \mathrm{Hg}, \mathrm{Ni}, \mathrm{K}, \mathrm{Se}, \mathrm{V}$, and $\mathrm{Zn}$ ) in water were determined by inductively coupled plasma optical emission spectrometry (ICP-OES) (Agilent Technologies, model 720 series) according to Standard Methods for the Examination of Water and Wastewater (WEF, 2005) methodology 3120B. Tables 2 and 3 show the conditions for determining these elements and system operation.

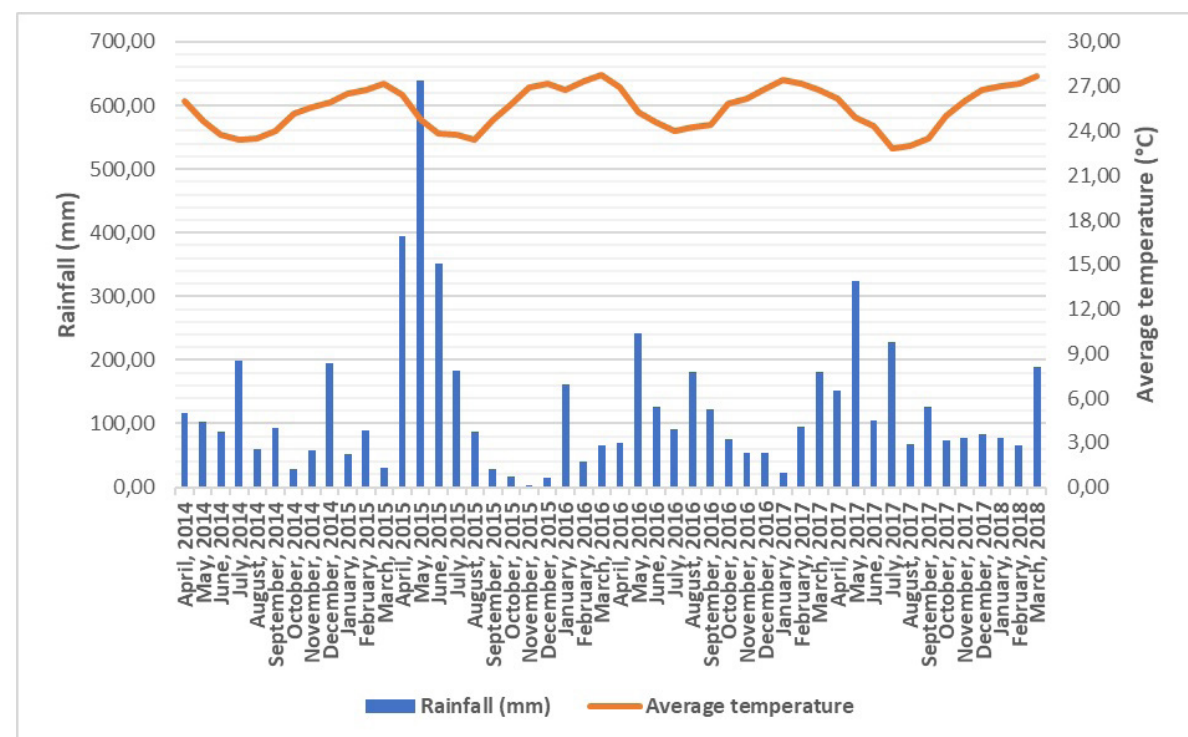

Figure 2. Histogram of monthly average temperature $\left({ }^{\circ} \mathrm{C}\right)$ and rainfall (mm) variation (April, 2014 - March, 2018). Data was obtained by the National Institute of Meteorology (INMET), in the city of Salvador.

Figura 2. Histograma da variação mensal média de temperatura $\left({ }^{\circ} \mathrm{C}\right)$ e pluviosidade (mm) (Abril, 2014 - Março, 2018). Dados obtidos pelo Instituto Nacional de Meteorologia (INMET), na cidade de Salvador.

Table 1. List of sampling points, dimensions of each lagoon, and their respective geographic coordinates.

Tabela 1. Lista dos pontos de amostragem, dimensões de cada lagoa e suas respectivas coordenadas geográficas

\begin{tabular}{ccccc}
\hline Lagoon & $\begin{array}{c}\text { Extension } \\
\left(\mathbf{m}^{\mathbf{2}}\right)\end{array}$ & Total of points & $\begin{array}{c}\text { Latitude } \\
\mathbf{( S )}\end{array}$ & Longitude $(\mathbf{O})$ \\
\hline Paixão & 75.212 & 2 & $12^{\circ} 51.185^{\prime}$ & $38^{\circ} 27.009^{\prime}$ \\
& & & $12^{\circ} 51.215^{\prime}$ & $38^{\circ} 26.952^{\prime}$ \\
Tororó & 110.122 & 4 & $12^{\circ} 58.919^{\prime}$ & $38^{\circ} 30.254^{\prime}$ \\
& & & $12^{\circ} 59.219^{\prime}$ & $38^{\circ} 30.490^{\prime}$ \\
& & & $12^{\circ} 59.147^{\prime}$ & $38^{\circ} 30.442^{\prime}$ \\
Pituaçú & 444.126 & \multirow{2}{*}{6} & $12^{\circ} 59.045^{\prime}$ & $38^{\circ} 30.304^{\prime}$ \\
& & & $12^{\circ} 57.820^{\prime}$ & $38^{\circ} 25.110^{\prime}$ \\
& & & $12^{\circ} 57.715^{\prime}$ & $38^{\circ} 24.783^{\prime}$ \\
& & & $12^{\circ} 57.620^{\prime}$ & $38^{\circ} 24.793^{\prime}$ \\
& & & $12^{\circ} 57.582^{\prime}$ & $38^{\circ} 25.063^{\prime}$ \\
& & & $12^{\circ} 57.464^{\prime}$ & $38^{\circ} 25.530^{\prime}$ \\
\hline
\end{tabular}


Table 2. System operating conditions for the determination of metal contents in water by inductively coupled plasma optical emission spectrometry (ICP-OES).

Tabela 2. Condições de operação do sistema para determinação das concentrações de metais em água por espectrometria de emissão óptica com plasma indutivamente acoplado (ICP-OES).

\begin{tabular}{cc}
\hline Parameters & Specifications \\
\hline Mist chamber & Cyclonic (Single Pass) \\
Nebulizer & SeaSpray \\
Radio Frequency Power & $1.10 \mathrm{~kW}$ \\
Plasma gas flow & $15 \mathrm{~L} \cdot \mathrm{min}^{-1}$ \\
Auxiliary gas flow & $1,5 \mathrm{~L} \cdot \mathrm{min}^{-1}$ \\
Mist gas flow & $0,75 \mathrm{~L} \cdot \mathrm{min}^{-1}$ \\
\hline
\end{tabular}

Table 3. Techniques, reference methods, quantification limits, and wavelengths for determining metal concentrations in water by coupled optical emission spectrometry with inductively coupled plasma (ICP-OES).

Tabela 3. Técnicas, métodos de referência, limites de quantificação e comprimento de onda para determinação das concentrações de metais em água por espectrometria de emissão óptica acoplada com plasma indutivamente acoplado (ICP-OES).

\begin{tabular}{|c|c|c|c|c|}
\hline Analysis & Technique & $\begin{array}{c}\text { Reference } \\
\text { Method }\end{array}$ & $\begin{array}{c}\text { Quantification } \\
\text { Limit }\end{array}$ & $\begin{array}{c}\text { Wavelength } \\
(\mathrm{nm})\end{array}$ \\
\hline Aluminum (Al) & ICP-OES & SM-3120B & $0,1 \mathrm{mg} \cdot \mathrm{L}-1$ & Al 396.153 \\
\hline Arsenic (As) & ICP-OES & SM-3120B & 0,0045 mg.L-1 & As 189.042 \\
\hline Barium (Ba) & ICP-OES & SM-3120B & 0,02 mg.L-1 & Ва 233.527 \\
\hline Boron (B) & ICP-OES & SM-3120B & 0,5 mg.L-1 & В 249.677 \\
\hline Cadmium (Cd) & ICP-OES & SM-3120B & $0,005 \mathrm{mg} \cdot \mathrm{L}-1$ & Cd 228.802 \\
\hline Calcium (Ca) & ICP-OES & SM-3120B & $0,010 \mathrm{mg} \cdot \mathrm{L}-1$ & Са 393.366 \\
\hline Chrome (Cr) & ICP-OES & SM-3120B & 0,02 mg.L-1 & Cr 267.716 \\
\hline Cobalt (Co) & ICP-OES & SM-3120B & 0,02 mg.L-1 & Co 228.615 \\
\hline Copper (Cu) & ICP-OES & SM-3120B & 0,01 mg.L-1 & Cu 324.754 \\
\hline Iron $(\mathrm{Fe})$ & ICP-OES & SM-3120B & 0,10 mg.L-1 & $\mathrm{Fe} 259.940$ \\
\hline Lead $(\mathrm{Pb})$ & ICP-OES & SM-3120B & 0,010 mg.L-1 & $\mathrm{Pb} 220.353$ \\
\hline $\begin{array}{l}\text { Magnesium } \\
(\mathrm{Mg})\end{array}$ & ICP-OES & SM-3120B & $0,5 \mathrm{mg} . \mathrm{L}-1$ & $\mathrm{Mg} 285.213$ \\
\hline $\begin{array}{l}\text { Manganese } \\
(\mathrm{Mn})\end{array}$ & ICP-OES & SM-3120B & $0,01 \mathrm{mg} \cdot \mathrm{L}-1$ & Mn 257.610 \\
\hline Mercury $(\mathrm{Hg})$ & ICP-OES & SM-3120B & 0,0012 mg.L-1 & $\mathrm{Hg} 292.4$ \\
\hline Nickel (Ni) & ICP-OES & SM-3120B & $0,02 \mathrm{mg} . \mathrm{L}-1$ & Ni 221.648 \\
\hline Potassium (K) & ICP-OES & SM-3120B & $0,8 \mathrm{mg} \cdot \mathrm{L}-1$ & K 206.279 \\
\hline Selenium (Se) & ICP-OES & SM-3120B & 0,03 mg.L-1 & Se 189.927 \\
\hline Vanadium (V) & ICP-OES & SM-3120B & $0,5 \mathrm{mg} \cdot \mathrm{L}-1$ & V 213.8 \\
\hline Zinc (Zn) & ICP-OES & SM-3120B & 0,005 mg.L-1 & Zn 213.857 \\
\hline
\end{tabular}

\section{Results}

The results of the analyzed variables were compared with the normative standards set by the legislation through the Ministry of Health Ordinance No. 2914/11 (Brasil, 2012) and CONAMA Resolution No. 357/2005 (Conama, 2005) for water quality according to identified uses.

\subsection{Physicochemical parameters}

The results of the physicochemical parameters of the water samples in the three studied lagoons are shown in table 4. Seasonal variations of the physicochemical parameters in the least rainy (drought) and wettest quadrant between 2014-2017 were illustrated in the boxplot diagrams in figure 3. Overall, the data show that 2016 was the most stable year in terms of physicochemical conditions and that turbidity values change most between seasons.

Temperature and Rainfall: Temperature and rainfall data during the sampling period are shown in figure 2. Rainfall patterns from the average precipitation reveal April, May, June, and July as the wettest four-month period, and August, September, October, and November as the driest one. The highest rainfall period was recorded in May 2015 (639 $\mathrm{mm}$ ) and the lowest in November of the same year $(3.20 \mathrm{~mm})$. 
The highest average temperature recorded occurred in March $2016\left(27.79{ }^{\circ} \mathrm{C}\right.$ ) and the lowest in July $2017\left(22.78{ }^{\circ} \mathrm{C}\right)$, corroborating the qualification and classification of sampling periods (dry and rainy seasons).

$\mathrm{pH}$ : pH ranged from neutral to slightly acidic at most collection points, except for some records at Tororó dike, where it was predominantly alkaline (Fig. 3A). At this point, $\mathrm{pH}$ ranged from 6.4 (rainy/2015) to 8.8 (rainy/2017), with a maximum standard deviation of 0.6. At Paixão lagoon, the lowest pH value was 6.1 (dry/2014) and the maximum was 8.2 (rainy/2017), with the highest standard deviation of 0.63 . At the Pituaçú Lagoon, where the neutral to the slightly alkaline character was predominant, the maximum $\mathrm{pH}$ value was 8.9 (dry/2015) and the minimum was 5.5 (dry/2016), with a maximum standard deviation of 1.46 .

Dissolved Oxygen: Dissolved Oxygen was one of the variables that presented greater distortions around the average, second only by turbidity variations (Tab. 4). At Tororó dike, the minimum value of this parameter found was 4.27 mg. $L^{-1}$ (dry/2017), whereas the maximum value was $8.42 \mathrm{mg}^{-1}$ (dry/2015) for this location, the standard deviation did not exceed $1.19 \mathrm{mg} . \mathrm{L}^{-1}$. At Paixão lagoon, the lowest dissolved oxygen value was $0.72 \mathrm{mg} . \mathrm{L}^{-1}$ (dry/2014) and the highest 9.75 mg. $L^{-1}($ rainy/2017), with a maximum standard deviation of 3.86. At Pituaçú lagoon, the highest value was $6.28 \mathrm{mg} . \mathrm{L}^{-1}$ (dry/2017) and the lowest $0.66 \mathrm{mg}$. L-1 (rainy/2017) with the highest standard deviation of 3.60 for this parameter.

Turbidity: Turbidity was the parameter that presented more variation and distant values around the sample mean. Tororó dike presented turbidity values ranging from 0.43 NTU (rainy/2015) to 34.08 NTU (rainy/2017), with a maximum standard deviation between points of 15.66. At Paixão lagoon, the minimum turbidity value was 3.26 NTU (rainy/2014) and the maximum 96.00 NTU (rainy/2015). At the Pituaçú lagoon turbidity values ranged from 23.97 NTU (dry/2016) to 123.90 NTU (rainy/2015). The maximum standard deviation for this point was 57.98, the highest found for this variable.

Conductivity: Among the variables considered, the conductivity presented the lowest values distortions around the means, reaching a maximum standard deviation of 0.51 at Pituaçú lagoon. At Tororó dike, its values ranged from $0.17 \mathrm{mS} . \mathrm{cm}-1$ (rainy/2017) to $0.37 \mathrm{mS} . \mathrm{cm}-1$, with a standard deviation of 0.09. At Paixão lagoon, the lowest value found was $0.21 \mathrm{mS} \mathrm{cm}^{-1}$ (dry/2016) and the highest $0.41{\mathrm{mS} . \mathrm{cm}^{-1}}^{-1}$ (rainy/2017). Its standard deviation was 0.07, the lowest among all parameters. At the Pituaçú lagoon, the extreme conductivity values were found in the dry period of 2014, with the minimum recorded $0.16 \mathrm{mS} \mathrm{cm}^{-1}$ and the maximum 0.88 $\mathrm{mS} . \mathrm{cm}^{-1}$.

\subsection{Metals}

The average values of the metals found are shown in table 5 . The metals whose results were found in all seasons and for all years below the limits of quantification were not listed for each lagoon. In general, the variations were similar among seasons, although the identified metals presented distinct behavior seasonally (dry/ rainy), spatially (at the different sampling points).

The average of the results obtained shows a preliminary profile of metal concentrations at Paixão and Pituaçú lagoons and Tororó dike where most of the results are below the limits allowed by CONAMA 357/05, or below the method quantification limits. Thus, it is coherent to separate them into two non-excluding groups: the first group of metals whose averages seen above the limit is punctual and a second, where variations in seasonal concentration were observed.

In the first group, where isolated peaks above the values allowed by CONAMA 357/2005 were observed, Fe stands out (max. $0.3 \mathrm{mg} \cdot \mathrm{L}^{-1}$ or $300 \mu \mathrm{g} . \mathrm{L}^{-1}$ ) at Tororó dike (dry season, 2015) and Pituaçú lagoon (dry season in 2014, 2016 and 2017); $\mathrm{Pb}$ (max. $0.01 \mathrm{mg} . \mathrm{L}^{-1}$ or $10 \mu \mathrm{g} . \mathrm{L}^{-1}$ ) in 2014 in both seasonal periods at Paixão and Pituaçú lagoons; and Al (max. limit $0.1 \mathrm{mg}^{-\mathrm{L}^{-1}}$ or $100 \mu \mathrm{g} . \mathrm{L}^{-1}$ ) at Pituaçú lagoon (rainy season, 2015). Mn was above the limits recommended by CONAMA 357 in all samples at Pituaçú lagoon, and Paixão lagoon was only below the limits in the dry seasons of 2016 and both seasons of 2017. 

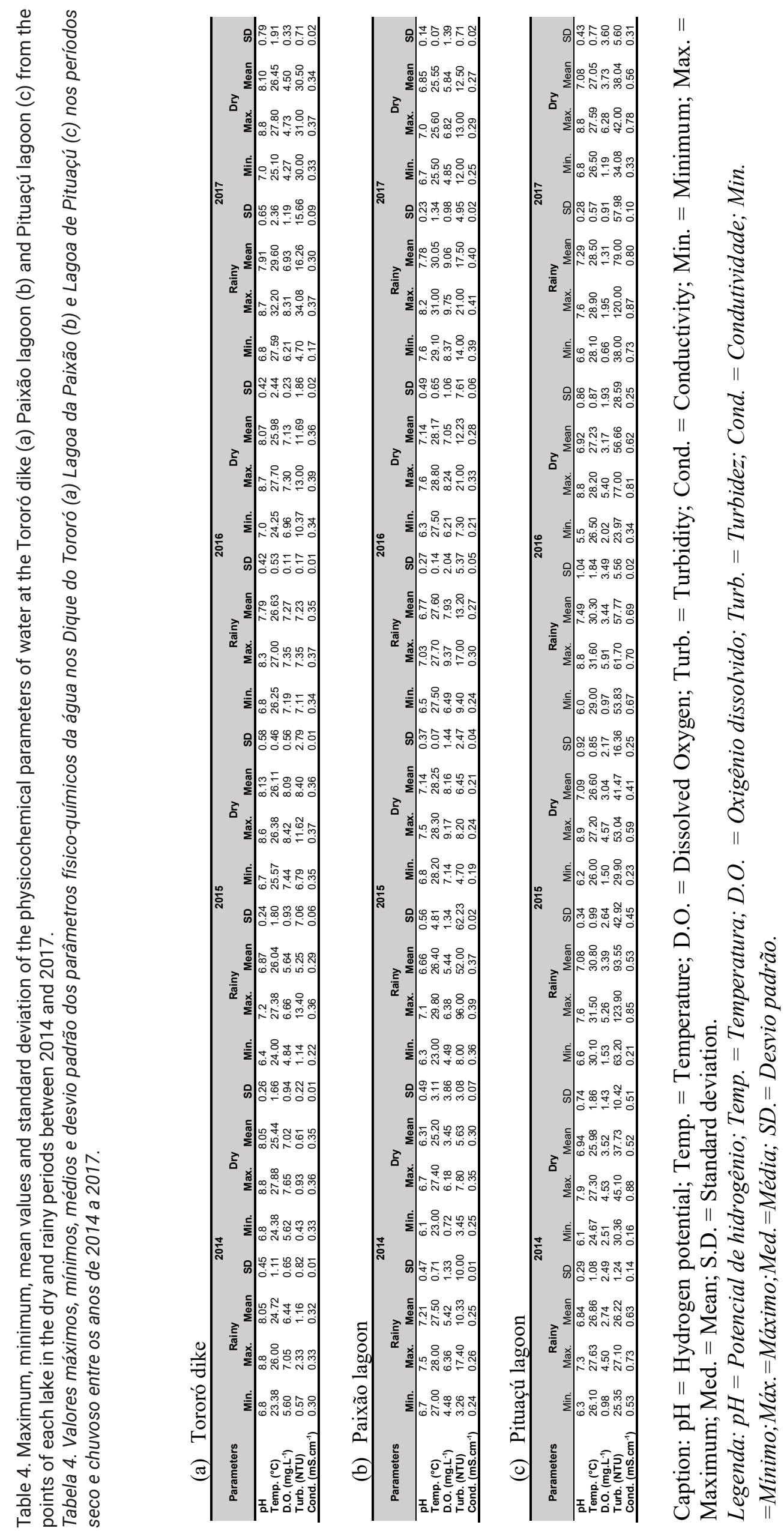

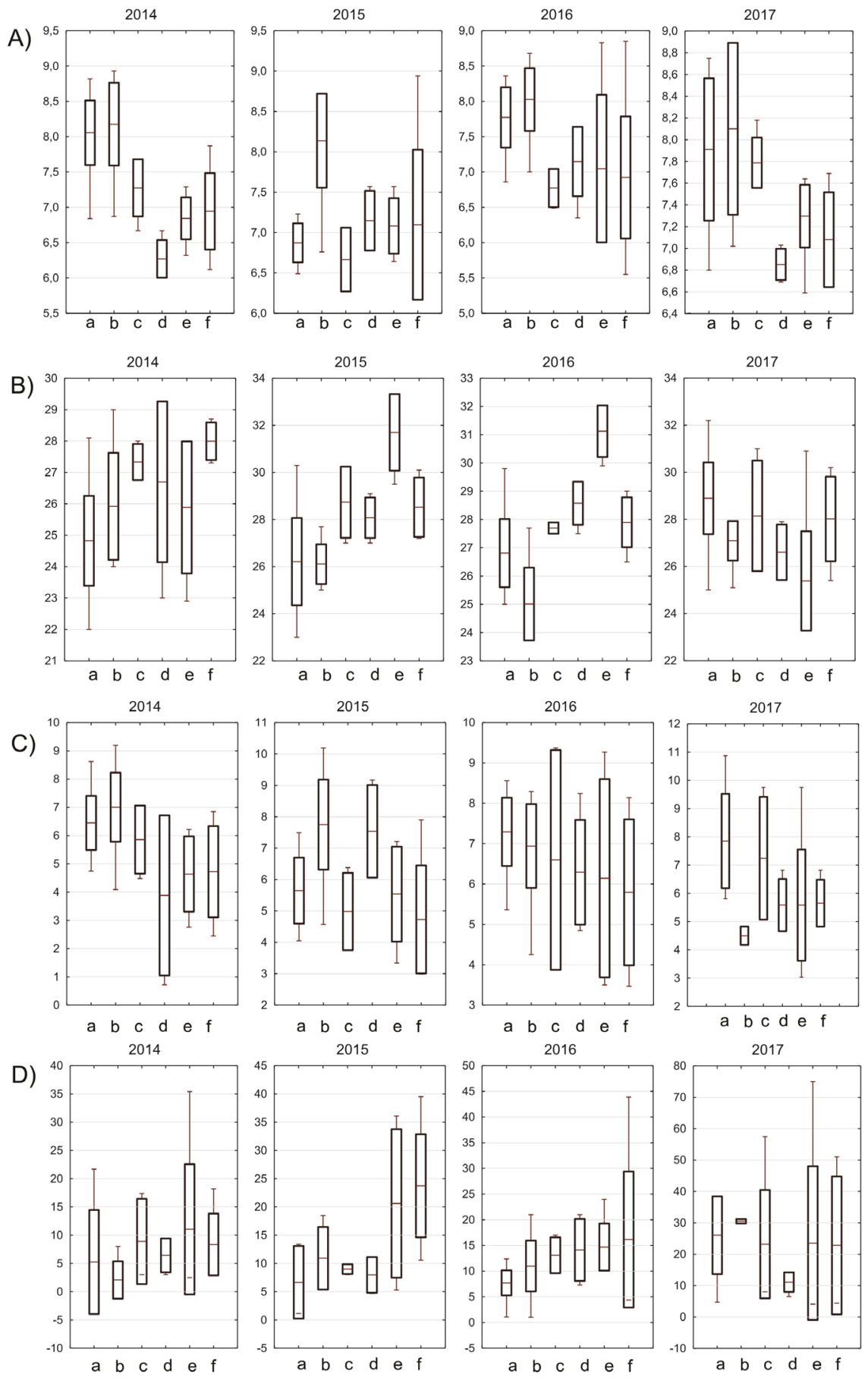

E)
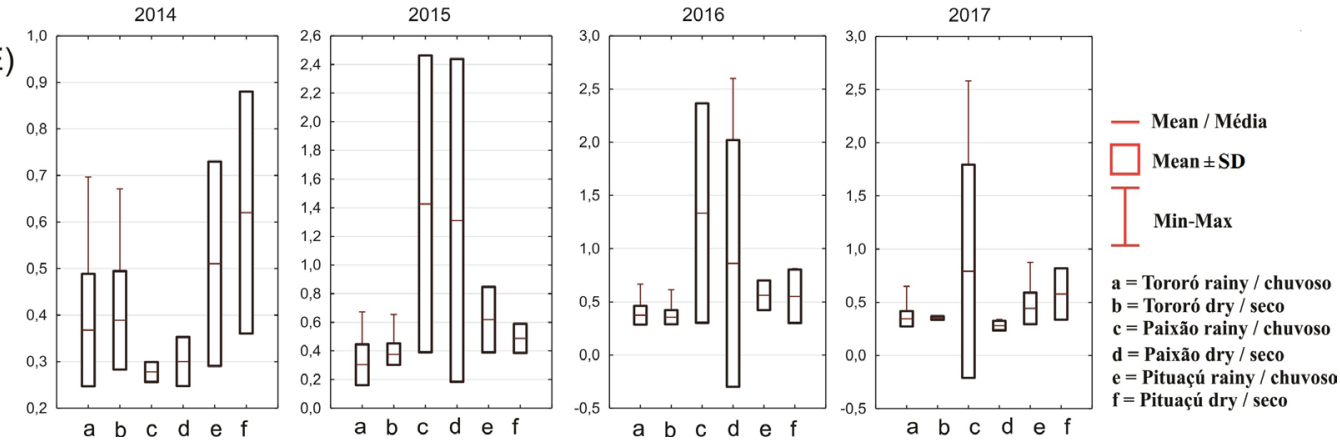

Figure 3. Boxplots illustrating the variation between the dry/rainy seasons of the mean, minimum and maximum values and standard deviation from 2014 to 2017 for the physicochemical variables: A) pH; B) Temperature $\left({ }^{\circ} \mathrm{C}\right)$; C) Dissolved oxygen (mg.L-1); D) Turbidity (NTU) and E) Conductivity (mS.cm ${ }^{-1}$.

Figura 3. Box-plots ilustrando a variação entre os períodos seco/chuvoso dos valores médios, mínimos e máximos e desvio padrão entre os anos de 2014 a 2017 para as variáveis físico-químicas: $A)$ pH; (B) temperatura ( ${ }^{\circ}$ C); C) oxigênio dissolvido

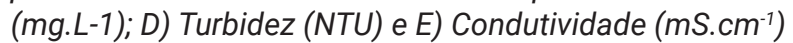


Table 5. Average values of metals found in water in Tororó dike, Paixão lagoon and Pituaçú lagoon in the dry and rainy periods from 2014 to 2017. Values in bold were found above the limits recommended by CONAMA 357/2005.

Tabela 5. Valores médios dos Metais encontrados na água nos Dique do Tororó, Lagoa da Paixão e Lagoa de Pituaçú nos períodos seco e chuvoso entre os anos de 2014 a 2017. Valores destacados em negrito foram encontrados acima dos limites preconizados no CONAMA 357/2005.

\begin{tabular}{|c|c|c|c|c|c|c|c|c|c|}
\hline \multirow{2}{*}{ Metals } & \multicolumn{2}{|l|}{2014} & \multirow{2}{*}{\begin{tabular}{|l|}
2015 \\
Rainy
\end{tabular}} & \multirow[b]{2}{*}{ Dry } & \multicolumn{2}{|l|}{2016} & \multicolumn{2}{|c|}{2017} & \multirow{2}{*}{$\begin{array}{c}\text { CONAMA 357/2005 } \\
\text { (ug.L-1) }\end{array}$} \\
\hline & Rainy & Dry & & & Rainy & Dry & Rainy & Dry & \\
\hline $\begin{array}{l}\text { Tororó dike } \\
\mathrm{Ca}\left(\mathrm{mgCa} \mathrm{L}^{-1}\right)\end{array}$ & 33,24 & 31,33 & 22,97 & 31,16 & 27,34 & 30,66 & 29,23 & 29,72 & - \\
\hline $\mathrm{Fe}\left(\mu \mathrm{gFe} . \mathrm{L}^{-1}\right)$ & 246,43 & 109,57 & 161,21 & 339,28 & 237,28 & 203,86 & 207,94 & 159,86 & 300 \\
\hline $\begin{array}{l}\left.\text { Mg (mgMg. } L^{-1}\right) \\
\left.\text { K (mg K. } L^{-1}\right) \\
\text { Paixão lagoon }\end{array}$ & $\begin{array}{l}5,76 \\
6,17\end{array}$ & $\begin{array}{l}7,56 \\
7,84\end{array}$ & $\begin{array}{l}8,30 \\
7,69\end{array}$ & $\begin{array}{l}5,24 \\
4,51\end{array}$ & $\begin{array}{l}6,14 \\
7,21\end{array}$ & $\begin{array}{l}5,79 \\
5,91\end{array}$ & $\begin{array}{l}7,31 \\
7,78\end{array}$ & $\begin{array}{l}6,49 \\
7,34\end{array}$ & - \\
\hline Al $\left(\mu \mathrm{gAl} . \mathrm{L}^{-1}\right)$ & $<L Q$ & 52,18 & $<\mathrm{LQ}$ & $<L Q$ & 19,13 & $<\mathrm{LQ}$ & $<\mathrm{LQ}$ & $<L Q$ & 100 \\
\hline As $\left(\mu \mathrm{gAs} . \mathrm{L}^{-1}\right)$ & $<\mathrm{LQ}$ & 0,85 & 1,56 & $<L Q$ & $<L Q$ & 2,59 & $<\mathrm{LQ}$ & $<L Q$ & 10 \\
\hline $\mathrm{Ba}\left(\mu \mathrm{gBa} \cdot \mathrm{L}^{-1}\right)$ & 97,61 & 16,12 & 11,34 & 11 & 12,8 & $<L Q$ & $<L Q$ & $<L Q$ & 700 \\
\hline B $\left(\mu \mathrm{gB} \cdot \mathrm{L}^{-1}\right)$ & 0,22 & $<\mathrm{LQ}$ & $<\mathrm{LQ}$ & 0,05 & $<\mathrm{LQ}$ & $<\mathrm{LQ}$ & $<L Q$ & $<\mathrm{LQ}$ & 500 \\
\hline Cd $\left(\mu g C d . L^{-1}\right)$ & 0,61 & $<\mathrm{LQ}$ & $<\mathrm{LQ}$ & $<\mathrm{LQ}$ & $<\mathrm{LQ}$ & $<\mathrm{LQ}$ & $<\mathrm{LQ}$ & $<\mathrm{LQ}$ & 1 \\
\hline $\mathrm{Pb}\left(\mu \mathrm{gPb} . \mathrm{L}^{-1}\right)$ & 481 & 35,60 & $<\mathrm{LQ}$ & $<\mathrm{LQ}$ & $<\mathrm{LQ}$ & $<\mathrm{LQ}$ & $<\mathrm{LQ}$ & $<L Q$ & 10 \\
\hline Co $\left(\mu g C_{0} . L^{-1}\right)$ & 22 & $<\mathrm{LQ}$ & $<\mathrm{LQ}$ & $<\mathrm{LQ}$ & $<\mathrm{LQ}$ & $<\mathrm{LQ}$ & $<\mathrm{LQ}$ & $<\mathrm{LQ}$ & 50 \\
\hline $\operatorname{Cr}\left(\mu \mathrm{gCr} \cdot \mathrm{L}^{-1}\right)$ & $<\mathrm{LQ}$ & $<\mathrm{LQ}$ & 0,86 & 1,62 & $<\mathrm{LQ}$ & 0,67 & $<\mathrm{LQ}$ & $<\mathrm{LQ}$ & 50 \\
\hline $\mathrm{Fe}\left(\mu \mathrm{gFe} . \mathrm{L}^{-1}\right)$ & 59,5 & 36,6 & 269 & 68,3 & 14,2 & 33,9 & 48,7 & 45,6 & 300 \\
\hline $\operatorname{Mn}\left(\mu \mathrm{gBa} \cdot \mathrm{L}^{-1}\right)$ & 104 & 286 & 124 & 106 & 104 & 54,7 & 50,2 & 39,1 & 100 \\
\hline $\mathrm{Hg}\left(\mu \mathrm{gHg} \cdot \mathrm{L}^{-1}\right)$ & 0,16 & $<\mathrm{LQ}$ & 0,1 & 0,11 & 0,12 & $<\mathrm{LQ}$ & $<\mathrm{LQ}$ & $<L Q$ & 0,2 \\
\hline$V\left(\mu g V . L^{-1}\right)$ & 0,8 & $<L Q$ & $<\mathrm{LQ}$ & $<L Q$ & 0,23 & 0,36 & 0,33 & 0,23 & 100 \\
\hline $\begin{array}{l}Z n\left(\mu g Z n . L^{-1}\right) \\
\text { Pituaçu lagoon }\end{array}$ & 13,1 & $<\mathrm{LQ}$ & 6,38 & $<L Q$ & 2,25 & $<\mathrm{LQ}$ & $<L Q$ & $<\mathrm{LQ}$ & 180 \\
\hline Al ( $\mu$ gAl.L) & 56,24 & 61,28 & 123,14 & $<\mathrm{LQ}$ & $<\mathrm{LQ}$ & $<\mathrm{LQ}$ & $<L Q$ & $<L Q$ & 100 \\
\hline As $\left(\mu \mathrm{g}\right.$ As. $\left.\mathrm{L}^{-1}\right)$ & 0,78 & 0,71 & 0,93 & 0,85 & 0,78 & $<\mathrm{LQ}$ & $<\mathrm{LQ}$ & $<L Q$ & 10 \\
\hline $\mathrm{Ba}\left(\mu \mathrm{g} \mathrm{Ba} \cdot \mathrm{L}^{-1}\right)$ & 115,44 & 57,41 & 54,9 & 50,57 & 60,52 & 61,48 & 51,2 & 63,4 & 700 \\
\hline B $\left(\mu g\right.$ B. $\left.L^{-1}\right)$ & 0,13 & 0,28 & 0,18 & $<L Q$ & $<\mathrm{LQ}$ & $<\mathrm{LQ}$ & $<L Q$ & $<L Q$ & 500 \\
\hline$C d\left(\mu g C d . L^{-1}\right)$ & 0,60 & 0,19 & $<L Q$ & $<\mathrm{LQ}$ & $<\mathrm{LQ}$ & $<\mathrm{LQ}$ & $<\mathrm{LQ}$ & $<\mathrm{LQ}$ & 1 \\
\hline $\mathrm{Pb}\left(\mu \mathrm{gPb} . \mathrm{L}^{-1}\right)$ & 97,54 & 10,61 & $<\mathrm{LQ}$ & $<\mathrm{LQ}$ & $<\mathrm{LQ}$ & $<\mathrm{LQ}$ & $<\mathrm{LQ}$ & $<\mathrm{LQ}$ & 10 \\
\hline Co $\left(\mu \mathrm{g} \mathrm{Co.L^{-1 }}\right)$ & 17,5 & $<L Q$ & $<L Q$ & $<L Q$ & $<L Q$ & $<L Q$ & $<L Q$ & $<L Q$ & 50 \\
\hline $\operatorname{Cr}\left(\mu \mathrm{g} \mathrm{Cr} \cdot \mathrm{L}^{-1}\right)$ & $<L Q$ & 2,728 & 10,31 & 2,3 & 3,70 & 4,36 & $<L Q$ & $<L Q$ & 50 \\
\hline $\mathrm{Fe}\left(\mu \mathrm{g} \mathrm{Fe} . \mathrm{L}^{-1}\right)$ & 206,95 & 366,36 & 175,43 & 200,74 & 96,46 & 313,6 & 176,5 & 330,1 & 300 \\
\hline$M n\left(\mu g M n \cdot L^{-1}\right)$ & 191,24 & 227,7 & 357,78 & 319,75 & 420,78 & 191,6 & 560,1 & 371,8 & 100 \\
\hline $\mathrm{Hg}\left(\mu \mathrm{g} \mathrm{Hg} \cdot \mathrm{L}^{-1}\right)$ & 0,13 & 0,15 & 0,105 & $<L Q$ & 0,12 & 0,11 & $<L Q$ & $<L Q$ & 0,2 \\
\hline Ag $\left(\mu g\right.$ Ag. $\left.L^{-1}\right)$ & $<\mathrm{LQ}$ & $<L Q$ & $<\mathrm{LQ}$ & 0,235 & $<\mathrm{LQ}$ & $<\mathrm{LQ}$ & $<L Q$ & $<L Q$ & 10 \\
\hline Se $\left(\mu \mathrm{g} \mathrm{Se} . \mathrm{L}^{-1}\right)$ & $<\mathrm{LQ}$ & $<\mathrm{LQ}$ & $<\mathrm{LQ}$ & 1,45 & $<\mathrm{LQ}$ & $<L Q$ & $<L Q$ & $<L Q$ & 10 \\
\hline $\mathrm{V}\left(\mu \mathrm{g} \mathrm{V} . \mathrm{L}^{-1}\right)$ & 3,87 & 4,28 & 12,78 & 0,72 & 3,79 & $<L Q$ & $<L Q$ & $<L Q$ & 100 \\
\hline$Z n\left(\mu g \operatorname{Zn} \cdot L^{-1}\right)$ & 52,54 & 10,41 & 47,07 & 27,58 & 8,91 & 7,38 & $<L Q$ & $<L Q$ & 180 \\
\hline
\end{tabular}

Caption: $<\mathrm{LQ}=$ below the method's limit of quantification.

Legenda: $\angle L Q=$ abaixo do limite de quantificação do método. 


\section{Discussion}

In the present study, the $\mathrm{pH}$ ranged from 5.5-8.9 (7.6 \pm 0.7$)$ for all environments analyzed. CONAMA recommends the $\mathrm{pH}$ conditions for Class 2 freshwater like Class 1 freshwater, defining as appropriate the $\mathrm{pH}$ remaining between 6.0 and 9.0, being only out of these limits the Pituaçú lagoon in the dry season of 2016 (Fig. $3 \mathrm{~A}) . \mathrm{pH}$ is a limiting factor for the colonization of aquatic ecosystems, as it determines survival, metabolism, physiology, and growth of these organisms and it is related to the presence of $\mathrm{H}+$ and $\mathrm{OH}$ - ions balanced with water molecules (Lawson, 2011).

The $\mathrm{pH}$ values found were consistent with studies conducted in other environments with similar thermal conditions and located in urban areas, ranging from neutral to slightly basic, such as Meneses et al. (2016), Sória et al. (2017), and Thebaldi et al. (2017). According to Abowei (2010), the ideal $\mathrm{pH}$ for biological productivity is between $7.0-8.5$ and $\mathrm{pH}$ values below 4.0 are harmful to aquatic life.

Water with a low $\mathrm{pH}$ value accelerates the corrosion of metallic materials as it provides an abundant supply of hydrogen ions. Although even pure water contains some free hydrogen ions, free carbon dioxide in water derived from the urban environment and the input of organic compounds can multiply the hydrogen ion concentration several times. When carbon dioxide dissolves in water, it reacts with water to form carbonic acid, a weak acid but an effective source of acidity (Rao \& Khan, 2000). Metals such as zinc (Zn) and cadmium ( $\mathrm{Cd}$ ) can have increased harmful environmental effects as a result of reduced $\mathrm{pH}$ (Langston, 2017).

The water temperature in the lagoons studied ranged from 22.0-33.20 (26.68 \pm 2.11$)$ ${ }^{\circ} \mathrm{C}$. Although the temperature does not have a limit specified by the environmental legislation (CONAMA Resolution 357), it is known that this parameter affects the electrical conductivity, its value increases from 2 to $3 \%$ for every $1^{\circ} \mathrm{C}$ (Lawson, 2011). Variations in water temperature between the different collections were not shown to be large, and it was not possible to define a variability pattern (Fig. 3B), since the strong influence of urban microclimates at different times affect water balance and temperature in these environments (Jeppesen et al., 2015). The environmental context of sampling also influences the factors found for temperature, which may be affected by reduction or absence of riparian forest and proximity to urban roads (observed in Tororó dike), the strong influence of solar radiation, channeled points, or eventual release of heated effluent (Alves et al., 2010). Temperature can also be an indirect measure of pollutant concentration, for domestic use, high temperatures can increase the toxicity of many substances, such as trace metals in water since temperature and $\mathrm{pH}$ are two important factors governing the methylation of elements such as arsenic (As), cadmium (Cd) and mercury ( $\mathrm{Hg})$ (Lawson, 2011).

The values found for dissolved oxygen ranged from a minimum of 0.72 to a maximum of $9.75\left(6.31 \pm 1.65 \mathrm{mg}^{-L^{-1}}\right)$. This wide variability is related to the different physiographic characteristics of the areas studied. According to the limits established by CONAMA Resolution 357, the measured limit of D.O. in class 2 freshwater shall not be less than $5 \mathrm{mg}$. $\mathrm{L}^{-1}$.

Dissolved molecular oxygen is the most important oxidizing agent in natural waters (Baird, 2001), and its solubility is controlled by several factors, such as atmospheric pressure, temperature, and salinity. Thus, lake waters in tropical regions, for example, as a result of thermal interference in the gas solubility, have less available oxygen than those of temperate aquatic environments. The main sources of oxygen for water are the atmosphere and photosynthesis. On the other hand, oxygen losses are caused by the consumption, decomposition of organic matter (oxidation), losses to the atmosphere, respiration of aquatic organisms, nitrification, and abiotic chemical oxidation of substances such as metal ions like Fe and Mn.

The low concentrations found for D.O., mainly at Pituaçú lagoon (Fig. 3C) where this effect was more frequent, are also related to the effect of seasonality on D.O. On the surface of tropical lakes, it is common to find hypoxia or even anoxic conditions as a result of the total mixing of the water body of different depths, with 
consequent reduction of oxygen concentration in the upper parts to $10 \%$ saturation levels (PratteSantos \& Simões, 2010). The presence of high concentrations of D.O. is also not convenient in waters in contact with iron and steel structures, as it favors corrosion and increase the bioavailability of metals, a scenario found in the underwater structure of statues and pedal boats located in Pituaçú lagoon and Tororó dike. The D.O. values not in accordance with legislation (CONAMA 357/05) indicate loss of water quality and risks to ecosystem structure and functioning; as well as the maintenance of ecosystem services, such as fishing, landscape harmony, carbon capture, contaminant immobilization, water quality, etc.

Geochemically, the rainy season explains the increase in turbidity (Fig. 3D), due to the higher outflow and carriage of materials to water bodies. Variations in turbidity values are dependent on abiotic (suspended particulate matter) or biotic (algae and microorganisms) factors. High concentrations of suspended solids reduce the passage of sunlight, affect metabolism and benthic organisms, and disrupt the food chain. For CONAMA, recommended class 2 freshwater turbidity values should not exceed 100 NTU. In this study, considering all points, the values were between 0.43-188.0 (23.54 \pm 31.86) NTU (Tab. 4).

The parameters of electrical conductivity and total dissolved solids tend to increase in the rainy season, since superficial outflow waters also carry large volumes of soil-leached ions (Peixoto et al., 2018). In the dry season due to the reduction of precipitation, less sediment is carried to the watercourses, reducing the amount of particulate matter suspended in the water and thus interfering with the radiation penetration process. Thus, it is possible to infer that higher rainfall indexes condition samples with higher turbidity results (Balistrieri et al., 1992).

The presence of suspended solids, and consequently turbidity, change the lighting conditions of the waters and the range of light radiation. At Tororó dike, there are reports of a strong odor and green color at the end of the rainy season, since the flow of organic matter and changes in the radiation range influence photosynthesis and consequently the growth of aquatic plants and plankton, a phenomenon that occurs especially in standing water or with the low flow velocity.

In the rainy season, electrical conductivity tended to be higher at almost all points (Fig. 3E). According to Peixoto et al. (2018), this fact is justified by the accumulation of organic matter during the dry season and subsequent carriage by the rain, causing variation in conductivity. The highest conductivity values were found at the points located within the urban perimeter, and the conductivity varied between $0.19-2.60$ $(0.44 \pm 0.35) \mathrm{mS} . \mathrm{cm}^{-1}$. Electrical conductivity determines the ability of a water body to transmit electric current and it is directly related to the concentration of dissolved ionic species, mainly inorganic, such as dissolving metals.

The measurement of electrical conductivity can be related to turbidity, a very sensitive parameter for the discharge of effluents and outflow of particulate material, which facilitates the assessment of water quality in this environment. At the points located within the urban perimeter, the highest conductivity values were found, suggesting anthropic interference in this parameter.

According to Silva et al. (2021), the turbidity caused by the leaching in association with the low depth of the studied lakes, promote the resuspension of the sediment, and consequent relocation of nutrients, especially phosphorus, whose concentrations analyzed in all surveyed lakes are above the limits established by CONAMA (2005), favoring algal growth. Furthermore, Aleluia et al. (2016), corroborates this information, as their research shows that trophic changes in water sources located in urban areas are also related to the input of allochthonous organic matter, and autochthonous production, which alters the rates of oxygen consumption due to degradation, promoting the formation of anoxia zones.

The degradation of water quality is evidenced in the concentration of metals with average values above the maximum limits. The points where contamination by dissolved metals is mainly determined by the elevation of $\mathrm{Al}$ and $\mathrm{Fe}$ concentrations, which inspire less environmental concern, because although they also cause condition changes in water quality, they are less toxic, not representing the greatest concern 
regarding toxicity, but revealing local conditions that define a different quality for these surface waters (Ribeiro et al., 2012).

$\mathrm{Fe}$ and $\mathrm{Mg}$ are important metals for the cellular processes of plants and animals and are naturally found in surface and groundwater as part of the biochemical and geochemical processes in aquifers and watersheds (Lawson, 2011). Iron content can, according to Esteves (1998), remove phosphate species from water through the coprecipitation process, immobilizing this limiting nutrient in the sediment. Therefore, iron, although less toxic to vertebrates and invertebrates, prone to bioaccumulation in aquatic macrophytes, can impact the phosphate distribution in the water column and the abundance and distribution of biota, in turn, the structure and functioning of lentic ecosystems.

Although the concentration of aluminum in water is controlled by organoleptic aspects, the concern about its incidence in aquatic bodies, especially those that may provide bioaccumulation due to fishing activities such as Pituaçú lagoon (in the rainy season, 2015), is its likely role in the incidence of Alzheimer's disease, and at high or long-term dosages, constipation, energy loss, abdominal cramps, memory loss, learning disability and osteoporosis (Freitas et al., 2001; Silva et al., 2010).

Manganese is also part of the group of metals naturally contained in the soil, along with iron and aluminum. Its source of contamination can also occur by contact of the body of water with steel, metal alloys, batteries, paints, varnish, and fertilizers. Another likely source of this pollutant in environments near urban centers is the combustion of tricarbonylmethylcyclopentadienyl manganese (MMT), particularly in areas of high traffic density (Lawson, 2011). It is an element of low toxicity and considerable biological importance, also easily identified in water sources contaminated through the manifestation of black spots (Mendes, 2007).

Manganese often occurs in surface waters with low oxygen concentrations, often in association with $\mathrm{Fe}$ and accumulates in certain fish species, and may become a public health concern, as chronic human exposure to elevated Mn levels may cause severe problems, causing mental and emotional disturbances, compromising locomotion and/or generating permanent brain and intestinal tract injuries (Viana et al., 2014).

Anomalies in metal values found in lake environments, as noted for $\mathrm{Pb}$ values in the Paixão lagoon in the 2014 rainy season, may occur due to the incorporation of strange metals into the body of water from anthropic activity, or by the contribution of elements participating in the hydrogeochemical cycles, from the constitution of the minerals that make up the particulate material and bottom sediment.

Concentrations of dissolved metals in the waters continually vary in response to the rates of various biogeochemical processes directly or indirectly driven by events taking place in the water column. Variations in physical and chemical parameters interfere with the reading of the concentration of these metals, for example, small $\mathrm{pH}$ variations may cause colloid precipitation causing a dragging process by occlusion or adsorption of different ions ( $\mathrm{Fe}, \mathrm{Al}$, $\mathrm{Pb}, \mathrm{Cd}, \mathrm{Ni}, \mathrm{Cr}, \mathrm{Cu}$, and $\mathrm{Mn}$ ). The precipitation of $\mathrm{Fe}$ oxyhydroxide, for example, occurs from $\mathrm{pH} 2.2$, as the $\mathrm{pH}$ increases, decreases in Fe concentrations are observed. (Yabe \& Oliveira, 1998). Therefore, it is observed that the variation of some metals may be related to $\mathrm{pH}$ changes, which increases or decreases the solubility of metal ions.

According to Aleluia et al. (2016) in the Pituaçu hydrographic basin, there are several anthropic activities with the potential to contribute metals to the water, including small industries, clinics, hospitals, and the drainage of urban roads. Thus, the irregular release of domestic effluents and the leaching process during runoff become additional factors in this extensive network of anthropic tensors that directly influences the water quality in this reservoir.

In the lagoon environment, heavy metals can occur linked to the suspended material or the bottom sediment, or dissolved in the water column and the interstitial water of the sediments. Therefore, the physical and chemical characteristics of these environments also reflect the geomorphology of the drainage system.

In this sense, the known presence of metals ( $\mathrm{Al}, \mathrm{Cu}, \mathrm{Fe}, \mathrm{Mn}$, and $\mathrm{V}$ ) stands out, described in 
previous studies in superficial sediments of the Pituaçú Lagoon (Silva et al., 2017) and on the banks of the Tororó Dike (Cr) (Tourinho \& Bereta, 2010), in addition to the presence of metallic species originating from minerals such as Fe (siderite, hematite, and goethite), Al (gibbsite) and Mn (manganite and pyrolusite).

These metals were identified as dissolved in sub saturation conditions in both the regolitic coverings and in the surface waters and underground drainage of the crystalline and fissural basement of the city of Salvador (Nascimento et al., 2009). Therefore, a more in-depth study of sedimentary cover in these aquatic systems is recommended to understand the geochemical processes associated with the presence of these metals in the surface waters of these environments.

Metallic contributions can also be related to metallic structures of urban leisure elements, such as statues and pedal boats, pier structures, and paint components. They may also be related to the accumulation of particles over time due to the proximity of the freeway (found at Tororo dike and Paixão lagoon). With the rainy season, the introduction of strange particles into the aquatic system is consequent, but, considering that most of the obtained levels were below the limit of quantification, although following the variations of seasonality, as a result of the observations, it is considered urgent and necessary interference to determine and reduce sources of $\mathrm{Mn}$ and Fe contamination.

\section{Conclusions}

In this study, the properties that determine the water quality in terms of physicochemical parameters and metal concentration at Pituaçú and Paixão lagoons and Tororó dike were monitored seasonally from 2014 to 2017. Values obtained for $\mathrm{pH}$, temperature, dissolved oxygen, turbidity, and conductivity are consistent with those recommended by CONAMA Resolution 357 for Class 2 freshwater. However, special attention is suggested for point variation in $\mathrm{pH}$ values and correction of dissolved oxygen depletion, especially at Tororó dike, where visual and odorous consequences of eutrophication at the end of the rainy season are often reported.

However, data on the concentration of metals in these locations which have been shown, seasonally (Iron, Lead, Manganese, and Aluminum) or constantly (as Manganese on Pituaçu and Paixão lagoon), at levels dangerously above the stipulated limits, pose a risk to ecosystem balance and the integrity of its current use (amateur fishing, recreation, conservation, and landscape harmony).

Therefore, it is emphasized the need for attention, highlighting the values that were obtained for dissolved metals due to the greater possibility of harmful effects, accenting the need for intervention and protection in these areas, followed by continuous monitoring, aiming to improve the water quality and respond to the prevailing uses by the local population. In conclusion, this study is a database for future ecological studies, conservation, and management of resources in this area, with the long-term objective that this information will allow a plan to be proposed with strategic and articulated actions with the government for the preservation and maintenance of public goods, with a view to the valorization and re-socialization of these environments.

Acknowledgments. This study was conducted and financed during a scholarship supported by the CNPq (National Council of Scientific and Technological Development) at the Federal University of Bahia within the Brazilian Ministry of Science, Technology, Innovation and Communications.

\section{References}

Abowei, J.F.N. 2010. Salinity, dissolved oxygen, $\mathrm{pH}$ and surface water temperature conditions in Nkoro River, Niger Delta, Nigeria. Advance Journal of Food Science and Technology, 2(1): 36-40.

Aleluia, F.T.F., Cruz, L., Freitas, J.D., Costa, M., Sousa, J.D., Leonidio, T.D.O. \& Carvalho, J.D. 2016. Monitoramento do Reservatório de Pituaçu, inserido na matriz de expansão urbana da cidade de Salvador, Bahia. Interfaces Científicas-Saúde e Ambiente-Aracaju, 5(1): 
$11-26$.

Alves, R.I.S., Tonani, K.A.A., Nikaido, M., Cardoso, O.O., Trevillato, T.M.B. \& Segura-Munoz, S.I. 2010. Avaliação das concentrações de metais pesados em águas superficiais e sedimentos do Córrego Monte Alegre e afluentes, Ribeirão Preto, SP, Brasil. Revista Ambiente \& Água, 5(3): 122-132.

Andrade, C.N. 2011. Biogeoquímica do ambiente estuarino do rio Passa Vaca em área urbana de Salvador, BA, 117p. Dissertação de Mestrado, Programa de Pós-graduação em Geologia, Instituto de Geociências, Universidade Federal da Bahia.

ABNT. Associação Brasileira De Normas Técnicas. 1987. Preservação e técnicas de amostragem de efluentes líquidos e corpos receptores: NBR9898. Rio de Janeiro, ABNT, 22p.

Baird, C. 2001. Química Ambiental. 2 ${ }^{\mathrm{a}}$ ed. Porto Alegre. Reverté, 844p.

Balistrieri, L.S., Murray, J.W. \& Paul, B. 1992. The biogeochemical cycling of trace metals in the water column of Lake Sammamish, Washington: Response to seasonally anoxic conditions. Limnology and Oceanography, 37(3): 529-548.

Barbosa, J.S.F., Correa-Gomes, L.C., Dominguez, J. M. L., Cruz, S. A. S. \& Souza, J. S. D. 2005. Petrografia e litogeoquimica das rochas da parte oeste do alto de Salvador, Bahia. Revista Brasileira de Geociências, 5(4): 9-22.

BRASIL. Ministério da Saúde. 2012. Portaria $n^{\circ}$ 2914 de 12 de dezembro de 2011. Dispõe sobre os procedimentos de controle e de vigilância da qualidade da água para consumo humano e seu padrão de potabilidade. Diário Oficial da União. Brasília, BRASIL, 10p.

Bonacin, A.L.S. 2001. Caracterização ambiental e estudo do comportamento do chumbo, zinco e boro em área degradada por indústrias cerâmicas-região dos lagos de Santa Gertrudes, São Paulo. São Paulo, 264p. Dissertação de Mestrado, Programa de Pós-graduação em Recursos Minerais e Hidrogeologia, Instituto de Geociências, Universidade de São Paulo.

Bucci, M.M.H.S., Delgado, F.E.D.F., Santos, C.D.S. \& Oliveira, L.F.C.D. 2015. Analysis of metallic, pesticide, physico-chemical and microbiological parameters of waters near the Dr. John Penido Dam, Juiz de Fora, MG. Revista Ambiente \& Água, 10(4): 804-824.

Carmo, J.C.C. 2015. Ferro nas águas subterrâneas do estado da Bahia: Fatores influentes na concentração e critérios alternativos de prospecção. Salvador, 146p. Dissertação de Mestrado, Programa de Pós-graduação em Engenharia Ambiental Urbana, Escola Politécnica, Universidade Federal da Bahia.

Chitmanat, C. \& Siripen, T. 2010. Spatial and temporal variations of physical-chemical water quality and some heavy metals in water, sediments and fish of the Mae Kuang River, Northern Thailand. International Journal of Agriculture and Biology, 12(6): 816-820.

CONAMA. Conselho Nacional de Meio Ambiente. 2005. Resolução n. 357 de 17 de março de 2005. Dispõe sobre a classificação dos corpos de água e diretrizes ambientais para o seu enquadramento, estabelece as Condições e padrões de lançamento de efluentes, e dá outras providências. Diário Oficial da União. Brasília, CONAMA, 27p.

Escobar, N.F.C. 2011. Estudo hidrogeoquímico nos estuários dos Rios Jaguaribe e PassaVaca, Salvador, BA. Salvador, 78p. Dissertação de Mestrado, Programa de Pós-graduação em Geoquímica, Petróleo e Meio Ambiente, Instituto de Geociências, Universidade Federal da Bahia.

Esteves, F. deA. 1998. Fundamentos de Limnologia. $2^{a}$ edição. Rio de Janeiro, Interciência, 602p.

Freitas, M.B., Brilhante, O.M. \& Almeida, L.M. 2001. Importância da análise de água para a saúde pública em duas regiões do Estado do Rio de Janeiro: enfoque para coliformes fecais, nitrato e alumínio. Cadernos de Saúde Pública, 17: 651-660.

Hillbricht-llkowska, A. \& Pieczynska, E. 2012. Nutrient dynamics and retention in land/ water ecotones of lowland, temperate lakes and rivers. Berlin, Springer Science and Business Media, 375p.

Jeppesen, E., Brucet, S., Naselli-Flores, L., Papastergiadou, E., Stefanidis, K., Noges, T. \& Bucak, T. 2015. Ecological impacts of global warming and water abstraction on lakes and reservoirs due to changes in water level and related changes in salinity. Hydrobiologia, 
750(1): 201-227.

Langston, W.J. 2017. Toxic effects of metals and the incidence of metal pollution in marine ecosystems. In: Furness R. W. Heavy metals in the marine environment. CRC Press, 101-120.

Lawson, E.O. 2011. Physico-chemical parameters and heavy metal contents of water from the Mangrove Swamps of Lagos Lagoon, Lagos, Nigeria. Advances in Biological Research, 5(1): 8-21.

Lindström, M. 2001. Urban land use influences on heavy metal fluxes and surface sediment concentrations of small lakes. Water, Air, and Soil Pollution, 126(3/4): 363-383.

Mendes, F.M. 2007. Estudo do uso da Moringa oleifera para remoção de prata e manganês em águas. Horizonte Científico, 1(1): 1-18.

Meneses, M.E.N., Costa, M.L. \& Costa, J.A.V. 2016. Os lagos do lavrado de Boa VistaRoraima: fisiografia, físico-química das águas, mineralogia e química dos sedimentos. Revista Brasileira de Geociências, 37(3): 478-489.

Nascimento, S.A.M., Barbosa, J.S.F., Cruz, M.J.M., \& de Lima, C.M. 2009. Hidrogeoquímica e índice de saturação dos minerais no sistema aqüífero do Alto Cristalino de Salvador, Bahia. Revista Brasileira de Geociências, 39(2): 230237.

Nascimento, S.A.M. \& Barbosa, J.S.F. 2010. Aspectos hidrogeológicos do Alto Cristalino de Salvador, Bahia. PLURAIS-Revista Multidisciplinar, 1(1): 144-158.

Nascimento, S.A.M. 2008. Diagnóstico hidrogeológico, hidroquímico e da qualidade da água do aqüifero freático do Alto Cristalino de Salvador-Bahia. Salvador, 214p. Tese de Doutorado, Programa de Pós-graduação em Geologia, Instituto de Geociências, Universidade Federal da Bahia.

Peixoto, J.D.S.G., Cunha, L.S., Rego, E.L. \& Araújo, D.F. 2018. Avaliação da qualidade dos recursos hídricos superficiais no alto curso da bacia hidrográfica do córrego Campo AlegreGoiás. Geochimica Brasiliensis, 31(1): 1-10.

Pratte-Santos, R. \& Simões, L.N. 2010. Estudo das variáveis físico-químicas em níveis de estratificação espacial em um ambiente lêntico na Reserva Biológica de Duas Bocas, Cariacica, Espírito Santo. Natureza online,
Santa Tereza, 8(2): 74-77.

Ramos, A.M., dos Santos, L.A.R. \& Fortes, L.T.G. 2009. Normais climatológicas do Brasil, 19611990. Instituto Nacional de MeteorologiaINMET, Brasília, Ministério da Agricultura, Pecuária e Abastecimento-MAPA, 465p.

Rao, D.P. \& Khan, M.A.Q. 2000. Zebra mussels: enhancement of copper toxicity by high temperature and its relationship with respiration and metabolism. Water Environment Research, 72(2): 175-178.

Ribeiro, E.V., Junior, A.P.M., Horn, A.H. \& Trindade, W.M. 2012. Metais pesados e qualidade da água do Rio São Francisco no segmento entre Três Marias e Pirapora-MG: Índice de contaminação. Revista Geonomos, 20(1): 4963.

Santos, A.D., Aragão, M.D.S., Correia, M.D.F., Santos, S.D., Silva, F.D. \& Araújo, H.D. 2016. Precipitação na cidade de Salvador: variabilidade temporal e classificação em quantis. Revista Brasileira de Meteorologia, 31(4): 454-467.

Santos, C.P.L. \& Lima, O.A.L. 2005. Análise Geofísica das Características Hidráulicas da Falha de Salvador na Região de ArembepeBahia. In: International Congress of the Brazilian Geophysical Society \& EXPOGEF, 9th, 2005, Salvador. Anais da Society of Exploration Geophysicists and Brazilian Geophysical Society, p. 822-825.

Santos, G.B. 2012. Análise multivariada de parâmetros químicos para avaliação ambiental da Lagoa Encantada, Ilhéus, Bahia. Salvador, 58p. Tese de Doutorado, Programa de Pósgraduação em Química, Universidade Federal da Bahia.

Silva, A.C.M., Azevedo, I.H.S., Gonçalves, M.V.P \& Cruz, M.J.M. 2021. Seasonal variability of water quality in urban lagoons in Northeast Brazil. Revista Geociências, 40(1): 207-220.

Silva, E., Souza, N.A., Viana, Z.C.V., Marinho, P.S. \& Santos, V.L.C.S. 2017. Concentração de metais em sedimentos da lagoa do Parque Metropolitano de Pituaçu, Bahia/Brasil. Holos, 4: 159-170.

Silva, F.B.B., Silva, H.K.P., Schuler, A.R.P. \& Albuquerque, G.B. 2010. Estudo preliminar das concentrações de metais traço, em 
águas subterrâneas na região metropolitana do Recife-Pernambuco de acordo com a Portaria MS n 518/gm de 25 de março de 2004. In: XVI CONGRESSO BRASILEIRO DE ÁGUAS SUBTERRÂNEAS E XVII ENCONTRO NACIONAL DE PERFURADORES DE POÇOS, São Luis. Anais do XVI Congresso Brasileiro de Águas Subterrâneas e XVII Encontro Nacional de Perfuradores de Poços, São Luis, 12p.

Sória, A.P., Torres, C.E. \& Kapusta, S.C. 2017. Avaliação de algumas variáveis da água do Lago da Praça dos Açorianos, Porto Alegre, RS-estação da primavera. ScientiaTec, 4(2): 198-207.

Souza, E.S. 2017. Caracterização hidrogeoquímica das lagoas costeiras do parque das dunas, Salvador-Bahia. Salvador, 97p. Dissertação de Mestrado, Programa de Pós-graduação em Geoquímica, Petróleo e Meio Ambiente, Instituto de Geociências, Universidade Federal da Bahia.

Souza, J.S., Barbosa, J.S. \& Gomes, L.C.C. 2010. Litogeoquímica dos granulitos orto derivados da cidade de Salvador, Bahia. Revista Brasileira de Geociências, 40(3): 339-354.

Thebaldi, M.S., Silva, A.V., Vilela, N.M.S., Leal, B.P., Borges, I.C., Martins, I.P. \& Fernandes, L.R. 2017. Concentração de nutrientes na água de duas lagoas urbanas do município de Formiga. Revista Brasileira de Engenharia de Biossistemas, 11(2): 172-184.

Tourinho, A.D.O. 2008. Estudo Histórico e Sócio Ambiental das Principais Fontes Públicas de Salvador. Salvador, 155p. Dissertação de mestrado, Programa de Pós-graduação em Engenharia Ambiental Urbana, Escola Politécnica, Universidade Federal da Bahia.

Tourinho, A., \& Beretta, M. 2010. Investigação da qualidade da água subterrânea utilizando as fontes naturais da cidade de Salvador. Águas Subterrâneas, 24(1): 73-82.
Viana, G.F.S., Carvalho, C.F., Nunes, L.S., Rodrigues, J.L.G., Ribeiro, N.S., Almeida, D.A., Ferreira, J.R.D., Abreu, N. \& Menezes-Filho, J.A. 2014. Noninvasive biomarkers of manganese exposure and neuropsychological effects in environmentally exposed adults in Brazil. Toxicology Letters, 231(2): 169-178.

WEF. Water Environmental Federation. 2005. Standard methods for the examination of water and wastewater. American Public Health Association (APHA): Washington, DC, USA, 1360p.

Yabe, M.J.S. \& Oliveira, E. 1998. Metais pesados em águas superficiais como estratégia de caracterização de bacias hidrográficas. Química Nova, 21(5): 551-556. 